\title{
GAYA KEPEMIMPINAN DAN MOTIVASI MEMPENGARUHI KINERJA PEGAWAI
}

\author{
Nurlina $^{1}$, Safrida $^{2}$, Musmulyadi $^{3}$, Burhan $^{4}$ \\ STIKI Makassar Indonesia ${ }^{1}$, STIE Bajiminasa Makassar Indonesia ${ }^{2}$ \\ IAIN Pare-Pare Indonesia ${ }^{3}$, Universitas Madako, Indonesia ${ }^{4}$ \\ nurlina290887@gmail.com ${ }^{1}$
}

\begin{abstract}
ABSTRAK
Penelitian ini bertujuan untuk mengetahui pengaruh gaya kepemimpinan dan motivasi terhadap kinerja pegawai Kemeterian Agama Provinsi Sulawesi Selatan. Penelitian ini menggunakan pendekatan kuantitatif, Sumber data primer dan sekunder. Pengumpulan data melalui penelitian lapangan dengan cara kuesioner dan dokumentasi. Adapun yang menjadi populasi dalam penelitian ini adalah seluruh pegawai yang berjumlah 232 orang pegawai negeri sipil. Untuk menentukan minimal sampel yang dibutuhkan digunakan rumus Slovin. Melalui perhitungan ukuran sampel maka diperoleh 69 orang sampel. Teknik analisis yang digunakan yaitu regresi linear berganda. Hasil penelitian, terdapat pengaruh positif dan signifikan secara parsial antara gaya kepemimpinan dan motivasi dengan kinerja pegawai. Faktor gaya kepemimpinan paling dominan mempengaruhi kinerja pegawai. Kepemimpinan dan motivasi kerja, berada pada kategori baik, dan sebaiknya kondis iini terus dipertahankan dan ditingkatkan.
\end{abstract}

Kata Kunci: Kepemimpinan, Motivasi, dan Kinerja

\section{ABSTRACT}

This study aims to determine the effect of leadership style and motivation on the performance of the employees of the Ministry of Religion of South Sulawesi Province. This research uses a quantitative approach, primary and secondary data sources. Collecting data through field research by means of questionnaires and documentation. As for the population in this study were all employees totaling 232 civil servants. To determine the minimum required sample, the Slovin formula is used. By calculating the sample size, 69 samples were obtained. The analysis technique used is multiple linear regression. The results showed that there was a partially positive and significant influence between leadership style and motivation on employee performance. The most dominant factor of leadership style influences employee performance. Leadership and work motivation are in the good category, and this condition should be maintained and improved.

Keywords: Leadership, Motivation, and Performance

\section{PENDAHULUAN}

Suatu organisasi dapat berjalan efektif apabila fungsi-fungsi manajemen seperti perencanaan, pengorganisasian, motivasi, kedisiplinan dan pengawasan yang ada di dalamnya berfungsi dengan baik, serta unsur-unsur penunjangnya 
tersedia dan memenuhi persyaratan. Salah satu unsur terpenting yang dapat mendukung jalannya perusahaan adalah sumber daya manusia (karyawan). Tenaga kerja atau sumber daya manusia dapat diartikan sebagai buruh, karyawan, pekerja atau pegawai yang memiliki keahlian dibidangnya masing-masing pada hakikatnya mempunyai maksud yang sama untuk mencapai suatu tujuan organisasi atau perusahaan. Dengan demikian, maka manajemen sumber daya manusia mempunyai peran penting dalam menentukan keberhasilan suatu perusahaan.

Sebagai kunci pokok, sumber daya manusia dapat menentukan keberhasilan pelaksanaan kegiatan dalam perusahaan. Oleh karena itu berhasil tidaknya suatu organisasi atau institusi akan ditentukan oleh faktor manusianya atau karyawannya dalam mencapai tujuannya. Seorang karyawan yang memiliki kinerja (hasil kerja atau karya yang dihasilkan) yang tinggi dan baik dapat menunjang tercapainya tujuan dan sasaran yang telah ditetapkan oleh suatu perusahaan.

Kinerja pegawai merupakan salah satu faktor utama yang dapat mempengaruhi kemajuan perusahaan. Semakin tinggi atau semakin baik kinerja pegawai maka tujuan perusahaan akan semakin mudah dicapai, begitu pula sebaliknya yang terjadi apabila kinerja pegawai rendah atau tidak baik maka tujuan itu akan sulit dicapai dan juga hasil yang diterima tidak akan sesuai keinginan perusahaan. Kinerja merupakan suatu hal yang tidak dapat dipisahkan dengan perusahaan. Dukungan dari perusahaan berupa pengarahan dari seorang pemimpin, motivasi yang diberikan sebagai penyemangat pegawai, tata tertib yang diterapkan, suasana kerja yang nyaman dan dukungan sumber daya seperti, memberikan peralatan yang memadai sebagai sarana untuk memudahkan pencapaian tujuan yang ingin dicapai sangat diperlukan untuk kinerja pegawai.

Seperti yang disampaikan Wibowo, (2017) terdapat peningkatan kinerja karyawan berdasarkan miotivasi karyawan. Kinerja pegawai merupakan salah satu faktor utama yang dapat mempengaruhi kemajuan perusahaan. Murti, (2013) motivasi berpengaruh signifikan pada kepuasaan kerja, motivasi tidak berpengaruh signifikan terhadap kinerja pegawai dan kepuasaan kerja berpengaruh signifikan terhadap kinerja pegawai. Tirtayasa, (2019) motivasi dan organisasi berpengaruh positif dalam kinerja seorang pegawai. Peningkatan kinerja karyawan akan membawa kemajuan bagi perusahaan untuk dapat bertahan dalam suatu persaingan lingkungan bisnis yang tidak stabil. Oleh karena itu upaya-upaya untuk meningkatkan kinerja merupakan tantangan manajemen yang paling serius karena keberhasilan untuk mencapai tujuan dan kelangsungan hidup perusahaan tergantung pada kualitas kinerja sumber daya manusia yang ada didalamnya.

Terdapat faktor negatif yang dapat menurunkan kinerja, diantaranya adalah menurunnya keinginan untuk mencapai prestasi kerja, kurangnya ketepatan waktu dalam penyelesaian pekerjaan sehingga kurang menaati peraturan, pengaruh yang berasal dari lingkungannya, teman sekerja yang juga menurun 
semangatnya dan tidak adanya contoh yang harus dijadikan acuan dalam pencapaian prestasi kerja yang baik. Semua itu merupakan sebab menurunya kinerja dalam bekerja. Faktor-faktor yang dapat digunakan untuk meningkatkan kinerja diantaranya adalah gaya kepemimpinan, motivasi, disiplin kerja.Widodo, (2012) lingkungan kerja, budaya organisasi, kepemimpinan sangat berpengaruh positif terhadap Kinerja. Marpaung, (2014) keberhasilan suatu unit usaha tergantung dari faktor kepemimpinan, teamwork dan kinerja para karyawan.

Terdapat beberapa fenomena yang terjadi pada kantor wilayah Kementerian Agama Provinsi Sulawesi-selatan. Kinerja pegawai selama ini dirasakan belum optimal, hal ini dapat dilihat dari masih adanya para pegawai yang meninggalkan kantor pada jam kerja dengan alasan yang tidak dapat dipertanggungjawabkan, ada oknum pegawai yang tidak ikut apel, cepat pulang sebelum waktunya tanpa alasan yang jelas, pegawai yang mangkir kerja dengan alasan kesehatan atau keperluan keluarga atau saling menyalahkan diantara sesama pegawai dalam melaksanakan pekerjaan dan masih rendahnya komitmen organisasi yang dimiliki pegawai. Penelitian ini menggunakan faktor kepemimpinan, motivasi, disiplin kerja, dalam melihat pengaruhnya terhadap kinerja pegawai negeri sipil pada kantor Kementerian Agama Provinsi Sulawesi-selatan karena faktor-faktor ini saat ini menjadi permasalah yang penting untuk dicarikan solusi demi meningkatkan kinerja secara berkelanjutan.

\section{METODE PENELITIAN}

Pendekatan dalam penelitian yakni pendekatan kuantitatif. Penelitian ini dilaksanakan pada kantor Wilayah Kementerian Agama Provinsi Sulawesi Selatan yang berlokasi di Jalan. Nuri No.53 Makassar. Sedangkan sumber data yang diperlukan dalam penelitian ini, bersumber dari data primer dan data Sekunder. Pengumpulan data melalui penelitian lapangan dilakukan dengan cara observasi ke lokasi penelitian. Teknik yang digunakan dengan cara ini adalah Kuesioner yaitu teknik pengumpulan data yang dilakukan peneliti melalui penyebaran kuesioner kepada responden. Dokumentasi yaitu pengumpulan data dengan mempelajari dokumen-dokumen perusahaan yang ada kaitannya dengan masalah yang akan diteliti khususnya mengenai faktor-faktor yang mempengaruhi kinerja pegawai. Adapun yang menjadi populasi dalam penelitian ini adalah seluruh pegawai yang berjumlah 232 orang pegawai negeri sipil. Untuk menentukan minimal sampel yang dibutuhkan jika ukuran populasi diketahui, digunakan rumus Slovin, dengan menggunakan formulasi sebagai berikut :

$n=\frac{N}{N(e)^{2}}$

Keterangan :

$\mathrm{n}=$ Jumlah sampel yang diambil

$\mathrm{N}=$ Jumlah populasi 
$\mathrm{e}^{2}=$ kelonggaran ketidak telitian karena kesalahan pengambilan

Berdasarkan pada pendapat di atas, maka penentuan jumlah sampel dapat dirumuskan sebagai berikut :

$$
N=\frac{232}{1+232(0,1)^{2}}=\frac{232}{(1=232 \times 0,01)}=\frac{232}{3,32}=70
$$

Dalam penelitian ini, jumlah populasi pegawai pada kantor wilayah kementerian Agama provinsi Sulawesi Selatan sebanyak 232 orang, dengan persentase $10 \%$, maka melalui perhitungan diatas, ukuran sampel yang diperoleh akan menjadi 69 orang. dibulatkan menjadi 70 responden. Teknik analisis yang digunakan s adalah regresi linear berganda dimana nilai dari variabel dependent dapat diperoleh dari hasil survei yang perhitungannya akan menggunakan skala likert. Data yang berhasil dikumpulkan dari kuisioner, selanjutnya akan diukur dengan pengukuran data ordinal dengan bobot hitung 1 sampai 5, dengan kategori: 1) kategori Sangat setuju dengan skor $=5$, 2) kategori Setuju dengan skor $=4,3$ ) kategori ragu- ragu dengan skor $=3$, 4) kategori Tidak setuju dengan skor $=2,5$ ) kategori sangat tidak setuju dengan skor $=1$

\section{HASIL PENELITIAN}

\section{Kepemimpinan}

Berdasarkan hasil penelitian melalui kuesioner yang telah diproses melalui tabulasi data menunjukkan adanya peningkatan partisipasi yang diperlihatkan oleh pegawai terutama dalam pelaksanaan tugas-tugas pokok dan fungsi khususnya yang bekerja dan berdomisili Kantor Kementerian Agama Provinsi Sulawesi Selatan. Peningkatan motivasi pegawai dapat ditunjukkan melalui beberapa fungsi yang mendukung yaitu adanya kemampuan kerja yang tinggi melalui gaya kepemimpinan yang relatif baik. Melalui hasil tabulasi data lapangan yang terkumpul dengan menggunakan jumlah responden sebanyak 70 orang pegawai yang analisisnya dapat ditunjukkan secara deskriptif dalam tabel 1 berikut ini :

Tabel 1 Frekuensi Tabel Responden terhadap Kepemimpinan

\begin{tabular}{cccccc}
\hline & \multicolumn{5}{c}{ X1 } \\
\hline \multirow{7}{*}{ Valid } & Frequency & Percent & Valid Percent & Cumulative Percent \\
\cline { 2 - 6 } & 2,20 & 1 & 1,5 & 1,5 & 1,5 \\
\cline { 2 - 6 } & 3,60 & 2 & 3,0 & 3,0 & 4,5 \\
\cline { 2 - 6 } & 3,80 & 7 & 10,6 & 10,6 & 15,2 \\
\cline { 2 - 6 } & 4,00 & 7 & 10,6 & 10,6 & 25,8 \\
\cline { 2 - 6 } & 4,20 & 6 & 9,1 & 9,1 & 34,8 \\
\cline { 2 - 6 } & 4,40 & 24 & 36,4 & 36,4 & 71,2 \\
\cline { 2 - 6 } & 4,60 & 17 & 25,8 & 25,8 & 97,0 \\
\cline { 2 - 6 } & 4,80 & 4 & 5,0 & 5,0 & 100,0 \\
\hline
\end{tabular}


Memperhatikan data tabel 1, maka indikator yang paling besar rata-ratanya ialah indikator ke-6 yaitu indikator Pemimpin mampu memberikan inspirasi kepada bawahanya Mampu menciptakan kreativitas dalam menyelesaikan pekerjaan, dengan rata-rata skor sebesar 36,4. Ini berarti, indikator yang paling besar kontribusinya pada pembentukan Kinerja pegawai ialah indikator Pemimpin mampu memberikan inspirasi kepada bawahanya. Sebaliknya, indikator yang paling kecil rata-rata skornya ialah indikator ke-1, pemimpin mampu memberikan arahan dan tugas kepada bawahanya dengan rata-rata 1,5. Berarti indikator ke-1 ini yang paling kecil kontribusinya pada pembentukan kinerja pegawai.

Memperhatikan hasil olah data dimaksud, maka secara deskriptif kinerja pegawai Kantor Kementerian Agama Provinsi Sulawesi Selatan cenderung bersaing untuk memperoleh indikator mampu menciptakan kreativitas dalam menyelesaikan pekerjaan. Namun ada gejala yang dapat memberi dampak ketidakstabilan pelaksanaan, yaitu ada kecenderungan pimpinan untuk mengabaikan mampu meningkatkan target pekerjaan. Jika kecenderungan ini tidak disadari oleh pimpinan sejak dini, dikhawatirkan pegawai akan berperilaku yang merugikan dirinya dan juga organisasi.

\section{Motivasi}

Berdasarkan hasil penelitian melalui kuesioner yang telah diproses melalui tabulasi data menunjukkan adanya peningkatan partisipasi yang diperlihatkan oleh pegawai terutama dalam pelaksanaan tugas-tugas pokok dan fungsi khususnya yang bekerja dan berdomisili Kantor Kementerian Agama Provinsi Sulawesi Selatan. Peningkatan motivasi pegawai dapat ditunjukkan melalui beberapa fungsi yang mendukung yaitu adanya kemampuan kerja yang tinggi melalui gaya kepemimpinan yang relatif baik. Melalui hasil tabulasi data lapangan yang terkumpul dengan menggunakan jumlah responden sebanyak 70 orang pegawai yang analisisnya dapat ditunjukkan secara deskriptif dalam tabel berikut ini :

Tabel 2 Frekuensi Tabel Tanggapan Responden terhadap Motivasi

\begin{tabular}{|c|c|c|c|c|c|}
\hline \multicolumn{6}{|c|}{$\mathrm{X} 2$} \\
\hline & & Frequency & Percent & Valid Percent & Cumulative Percent \\
\hline \multirow[t]{9}{*}{ Valid } & 3,00 & 1 & 1,5 & 1,5 & 1,5 \\
\hline & 3,20 & 1 & 1,5 & 1,5 & 3,0 \\
\hline & 3,80 & 1 & 1,5 & 1,5 & 4,5 \\
\hline & 4,00 & 7 & 10,6 & 10,6 & 15,2 \\
\hline & 4,20 & 15 & 22,7 & 22,7 & 37,9 \\
\hline & 4,40 & 7 & 10,6 & 10,6 & 48,5 \\
\hline & 4,60 & 12 & 14,1 & 14,1 & 62,6 \\
\hline & 4,80 & 26 & 39,4 & 39,4 & 100,0 \\
\hline & Total & 70 & 100,0 & 100,0 & \\
\hline
\end{tabular}


Memperhatikan data tabel 2, maka indikator yang paling besar rata-ratanya ialah indikator ke- 8 yaitu indikator pegawai Mampu berkomunikasi dengan rekan kerja secara baik sehingga tercipta kekerabatan yang erat, dengan rata-rata skor sebesar 39,4. Ini berarti, indikator yang paling besar kontribusinya pada pembentukan Kinerja pegawai ialah indikator pegawai Mampu berkomunikasi dengan rekan kerja secara baik sehingga tercipta kekerabatan yang erat. Sebaliknya, indikator yang paling kecil rata-rata skornya ialah indikator ke-1, pemimpin mampu memberikan arahan dan tugas kepada bawahanya dengan ratarata 1,5. Berarti indikator ke-1 ini yang paling kecil kontribusinya pada pembentukan kinerja pegawai. Memperhatikan hasil olah data dimaksud, maka secara deskriptif kinerja pegawai Kantor Kementerian Agama Provinsi Sulawesi Selatan cenderung bersaing untuk memperoleh indikator pegawai Mampu berkomunikasi dengan rekan kerja secara baik sehingga tercipta kekerabatan yang erat. Namun ada gejala yang dapat memberi dampak ketidakstabilan pelaksanaan, yaitu ada kecenderungan pimpinan untuk mengabaikan mampu meningkatkan target pekerjaan.

\section{PEMBAHASAN}

Hasil pengujian hipotesis menunjukkan bahwa gaya kepemimpinan mempunyai pengaruh yang signifikan terhadap kinerja pegawai. Ini memberikan makna gaya kepemimpinan mempunyai pengaruh positif yang signifikan terhadap kinerja pegawai. Maka kepemimpinan adalah suatu proses dimana seseorang mempengaruhi orang lain untuk menjadi bawahan dalam mencapai tujuan bersama.

Memperhatikan hasil olah data dimaksud, maka secara deskriptif kinerja pegawai Kantor Kementerian Agama Provinsi Sulawesi Selatan cenderung bersaing untuk memperoleh indikator mampu menciptakan kreativitas dalam menyelesaikan pekerjaan. Pengaruh gaya kepemimpinan terhadap kinerja karyawan, Thoha (2010), mengungkapkan bahwa dengan mempergunakan kepemimpinan maka pemimpin akan mempengaruhi persepsi bawahan dan memotivasinya, dengan cara mengarahkan karyawan pada kejelasan tugas, pencapaian tujuan, kepuasan kerja, dan pelaksanaan kerja yang efektif.

Peningkatan motivasi pegawai dapat ditunjukkan melalui beberapa fungsi yang mendukung yaitu adanya kemampuan kerja yang tinggi melalui gaya kepemimpinan yang relatif baik. Melalui hasil tabulasi data lapangan yang terkumpul dengan menggunakan jumlah responden sebanyak 70 orang pegawai. Kartono (2008), menjelaskan bahwa gaya kepemimpinan adalah cara bekerja dan bertingkah laku pemimpin dalam membimbing para bawahannya untuk membuat sesuatu. Jadi gaya kepemimpinan merupakan sifat dan perilaku pemimpin yang diterapkan kepada bawahannya untuk membimbing bawahannya dalam melaksanakan pekerjaan. Wirawan (2009) menyebutkan jika kinerja adalah keluaran yang dihasilkan oleh fungsi-fungsi atau indikator-indikator suatu 
pekerjaan atau suatu profesi dalam waktu tertentu. Jadi kinerja karyawan adalah hasil yang dicapai seseorang dalam melaksanakan tugas yang diberikan kepadanya sesuai dengan kriteria yang telah ditetapkan.

\section{SIMPULAN}

Secara simultan kedua variabel bebas, yakni gaya kepemimpinan, motivasi kerja, berpengaruh positif dan signifikan terhadap kinerja pegawai. Secara parsial gaya kepemimpinan berpengaruh positif dan signifikan terhadap kinerja pegawai. Terdapat pengaruh positif dan signifikan secara parsial antara Gaya kepemimpinan dengan kinerja pegawai. Faktor gaya kepemimpinan paling dominan pengaruhnya terhadap kinerja pegawai. Kepemimpinan dan motivasi Kerja berada pada kategori baik, dan sebaiknya kondisiini terus dipertahankan dan ditingkatkan

\section{DAFTAR PUSTAKA}

Kartono, K. (2008). Pemimpin dan Kepemimpinan. Jakarta: PT. Raja Grafindo Persada.

Marpaung, M. (2014). Pengaruh kepemimpinan dan Teamwork Terhadap kinerja karyawan Di koperasi sekjen kemdikbud senayan jakarta. Jurnal Ilmiah WIDYA, 1(1).

Murti, H., \& Srimulyani, V. A. (2013). Pengaruh Motivasi Terhadap Kinerja Pegawai Dengan Variabel Pemediasi Kepuasaan Kerja Pada PDAM Kota Madiun. JRMA| Jurnal Riset Manajemen dan Akuntansi, 1(1), 10-17.

Tirtayasa, S. (2019). Pengaruh Kepemimpinan, Budaya Organisasi, dan Motivasi terhadap Kinerja Pegawai. Maneggio: Jurnal Ilmiah Magister Manajemen, 2(1), 45-54.

Thoha, M. (2010). Pembinaan Organisasi Proses dianosa dan intervensi Manajemen Kepemimpinan. Yogyakarta Gava Media.

Wibowo, I., \& Saputra, W. (2017). Pengaruh Gaya Kepemimpinan terhadap Kinerja Pegawai melalui Disiplin dan Motivasi Kerja Pegawai PPSU Kelurahan Duren Sawit Jakarta Timur. Jurnal Manajemen Bisnis Krisnadwipayana, 5(2).

Widodo, T. (2012). Pengaruh Lingkungan Kerja, Budaya Organisasi, Kepemimpinan terhadap Kinerja (Studi Pada Pegawai Kecamatan Sidorejo Kota Salatiga). Among Makarti, 3(5).

Wirawan. (2009). Pengaruh Kinerja Sumber Daya Manusia Teori Aplikasi dan Penelitian . Jakarta. :Salemba Empat. 